\title{
IDENTIFIKASI FRAGMEN DNA MITOKONDRIA PADA SATU GARIS KETURUNAN IBU DARI SEL EPITEL RONGGA MULUT DAN SEL FOLIKEL AKAR RAMBUT
}

\author{
Rina Budi Satiyarti ${ }^{1}$, Nurmilah ${ }^{2}$, Tina Dewi Rosahdi ${ }^{2}$ \\ ${ }^{1}$ UIN Raden Intan Lampung Jalan Letkol H. Endro Suratmin Bandar Lampung \\ ${ }^{2}$ UIN Sunan Gunung Jati Bandung Jalan A.H. Nasution No. 105 Kota Bandung \\ Email : rinabudi07@gmail.com
}

Diterima: 22 Mei 2017. Disetujui : 19 Juni 2017. Dipublikasikan: 29 Juni 2017

\begin{abstract}
Abstrak: DNA mitokondria (mtDNA) manusia memiliki sejumlah sifat genetik khas yang membedakannya dari genom inti yang dimanfaatkan dalam identifikasi penurunan hubungan kekerabatan, studi evolusi dan migrasi global manusia modern, bidang forensik dan identifikasi penyakit genetik. DNA mitokondria (mtDNA) manusia memiliki laju mutasi yang lebih cepat dibandingkan dengan DNA inti sehingga dapat dimanfaatkan untuk pemeriksaan sampel yang terbatas seperti untuk kepentingan visum. Penelitian ini bertujuan untuk megidentifikasi fragmen DNA mitokondria dari lisis sel epitel rongga mulut menggunakan primer M1dan HV2R, dan sel folikel akar rambut mengunakan primer M1 dan M2 dengan teknik PCR dan elektroforesis agarosa.Sampel sel epitel mulut dan akar rambut yang diambil dari satu garis keturunan dilisis terlebih dahulu dan dilakukan ekstraksi sel secara kimiawi dan enzimatik sehingga DNA total dapat keluar dari inti sel dan mitokondria. Setelah itu dilakukan amplifikasi fragmen D-loop mtDNA secara in vitro dengan dua jenis primer yang berbeda menggunakan teknik PCR dan proses terakhir yaitu dilakukan analisis hasil PCR menggunakan teknik elektroforesis gel agarosa. Hasil penelitian menunjukkan bahwa amplifikasi fragmen DNA mitokondria menggunakan primer $\mathrm{M} 1$ dan $\mathrm{HV} 2 \mathrm{R}$ dari sel epitel rongga mulut menghasilkan fragmen berukuran $1 \mathrm{~kb}$. Pada hasil amplifikasi fragmen DNA mitokondria dari sel folikel akar rambut menggunakan primer M1 dan M2, fragmen yang didapatkan berukuran 0,4-0,5 kb. Dengan demikian, fragmen DNA mitokondria dapat diamplifikasi menggunakan dua primer balik M2 dan HV2R yang dirancang pada ujung daerah D-LOOP mitokondria.
\end{abstract}

Kata Kunci: mtDNA, PCR, epitel, folikel, fragmen, primer.

\section{PENDAHULUAN}

DNA mitokondria (mtDNA) manusia memiliki sejumlah sifat genetik khas yang membedakannya dari genom inti. Pada mamalia, DNA mitokondria hanya diturunkan melalui jaluribu tanpa rekombinasi. mtDNA pada sel anak seluruhnya disumbangkan oleh ibu dan sperma sama sekali tidak berkontribusi. ${ }^{[1]}$ Keunikansistem penurunan yang menarik ini telah dimanfaatkan dalam berbagai bidang yaitu penurunan hubungan kekerabatan, studi evolusi dan migrasi global manusia modern, bidang forensik dan identifikasi penyakit genetik. ${ }^{[2]}$

Keunikan lain dari mtDNA yaitu memiliki laju mutasi yang lebih tinggi dibandingkan dengan DNA inti yaitu laju mutasi menetap gen-gen mtDNA 10-17 kali lebih cepat daripada yang terlibat dalam fosforilasi oksidatif yang dikode oleh DNA inti. ${ }^{[2]}$ mtDNA berbeda dengan DNA inti pada lokasi, urutan, kuantitas dalam sel, dan cara pewarisannya (dari orang tua ke anak). Sel hanya memiliki satu inti sel yang mengandung 2 set kromosom, yaitu satu set paternal 
dan satu set maternal, masing-masing set terdiri dari 23 kromosom. Akan tetapi sel dapat mengandung ratusan hingga ribuan mitokondria dan masing-masing mitokondria dapat mengandung beberapa kopi mtDNA.DNA inti memiliki jumlah basa yang lebih banyak dibandingkan mtDNA, tetapi molekul mtDNA terdapat dalam jumlah kopi yang jauh lebih banyak daripada molekul DNA inti. Karakteristik mtDNA ini sangat berguna pada situasi ketika jumlah DNA dalam sampel sangat terbatas, seperti sampel-sampel yang diambil dari kasus kriminal yaitu rambut, tulang, gigi, cairan tubuh (air liur, air mani, darah). ${ }^{[3]}$

Metode Polymerase chain reaction (PCR) digunakan untuk membuat jutaan kopi DNA dari sampel biologis. Amplifikasi DNA dengan menggunakan PCR hanya membutuhkan sedikit sampel dan dapat diperoleh dari sampel yang halus seperti rambut. Kemampuan PCR untuk mengamplifikasi sejumlah kecil DNA memungkinkan untuk menganalisis sampel yang sudah terdegradasi sekalipun. Namun, tetap saja harus dicegah kontaminasi dengan materi biologis yang lain selama melakukan identifikasi, dan menyiapkan sampelnya. ${ }^{[4]}$ Tes DNA dilakukan dengan cara mengambil DNA dari kromosom sel tubuh (autosom) yang mengandung area STR (short tandem repeats), suatu area ini tidak memberi kode untuk melakukan sesuatu. STR inilah yang bersifat unik karena berbeda pada setiap orang. Perbedaannya terletak pada urutan pasang basa yang dihasilkan dan urutan pengulangan STR. Pola STR ini diwariskan dari orang tua.

Metode elektroforesis gel didasarkan pada pergerakan molekul bermuatan dalam media penyanggah matriks stabil dibawah pengaruh medan listrik. Media yang umum digunakan adalah gel agarosa atau poliakrilamid. Elektroforesis gel agarosa digunakan untuk memisahkan fragmen DNA yang berukuran lebih besar dari 100 bp dan dijalankan secara horizontal, sedangkan elektroforesis akrilamid dapat memisahkan 1 bp dan dijalankan secara vertikal. Manfaat elektroforesis gel yaitu untuk mengetahui ukuran fragmen DNA dari produk PCR.

Penelitian ini merupakan bagian dari upaya mendapatkan ukuran fragmen mtDNA manusia pada satu garis keturunan ibu menggunakkan 2 jenis primer, dimana sampel sel epitel rongga mulut menggunakan primer $\mathrm{M} 1$ dan HV2R dan sampel sel folikel akar rambut menggunakan primer M1dan M2.Penelitian ini secara khusus bertujuan untuk melakukan amplifikasi ukuran fragmen $0,4 \mathrm{~kb}(443 \mathrm{pb})$ pada sampel akar rambut pada satu garis keturunan ibu dan amplifikasi ukuran fragmen $1 \mathrm{~kb}(1000 \mathrm{pb})$ pada sampel sel epitel rongga mulut pada satu garis keturunan ibu.

Tubuh manusia tersusun atas sel yang membentuk jaringan, organ, hingga sistem organ.Sel mengandung materi genetik yang terdiri dari DNA dan RNA. Molekul DNA merupakan rantai polinukleotida berbentuk heliks ganda yang mempunyai beberapa jenis basa purin dan pirimidin.$^{[6]}$

\section{Sel}

Sel merupakan unit struktural dan fungsional organisme hidup. Organisme terkecilterdiri dari sel tunggal, sebaliknya tubuh manusia mengandung sedikit $10^{14}$ sel. Terdapat berbagai jenis sel, yang amat bervariasi dalam ukuran, bentuk dan fungsi khususnya. Tiap sel dikelilingi oleh membran tipis yang membuatnya terpisah dan mencukupi diri sendiri. Membran sel disebut juga membran plasma atau membran sitoplasma yang bersifat permeable. Didalam tiap sel terdapat sitoplasma, tempat berlangsungnya hampir semua reaksi enzimatis dari metabolisme sel. Dalam sitoplasma, energi kimia digunakan oleh sel untuk membangun dan mempertahankan strukturnya. Didalam sitoplasma sel juga terdapat ribosom, suatu granula kecil yang berdiameter 18 sampai $22 \mathrm{~nm}$, yang berfungi mensintesis protein. Dan semua sel hidup dilengkapi dengan inti 
sel dimana tempat terjadinya replikasi senyawa genetik dan penyimpanan dalam bentuk asam deoksiribonukleat (DNA). ${ }^{[7]}$

Organisme yang hidup saat ini dibagi dalam dua kelompok besar, yaitu prokariot dan eukariot.Sel prokariot merupakan sel terkecil yang paling sederhana. Berikut gambar sel prokariot dapat dilihat pada Gambar 1.

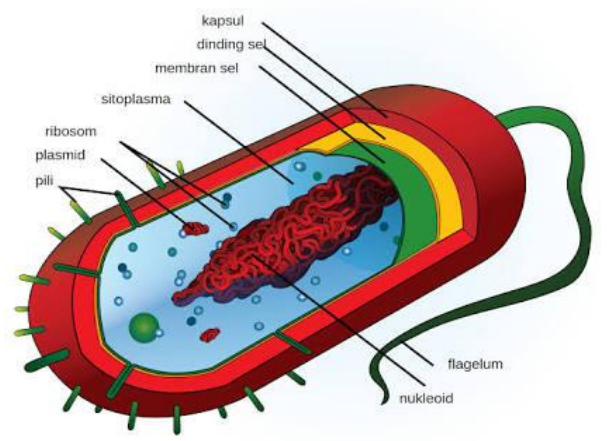

Gambar 1.Sel prokariot. ${ }^{[8]}$

Sel prokariot kira-kira terdiri dari 3000 spesies bakteri, termasuk organisme yang disebut ganggang hijau-biru. Sel prokariot memiliki struktur yang sederhana, pertumbuhan sel nya sangat cepat, mekanisme sederhana dan transmisi informasi genetik.Sedangkan sel eukariot berukuran lebih besar dibandingkan dengan sel prokariot. Sel eukariot dapat dilihar pada Gambar 2.

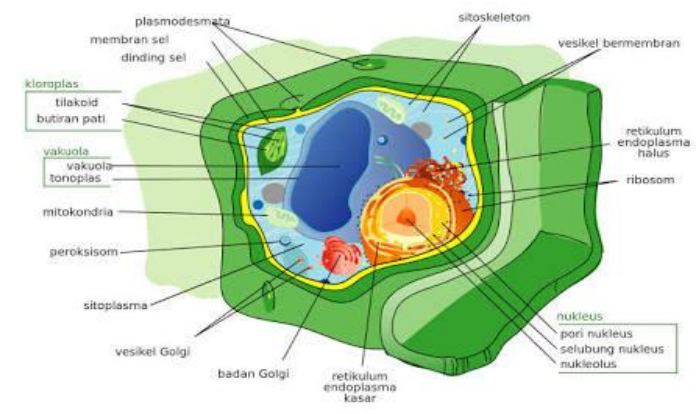

Gambar 2.Sel eukariot. $^{[9]}$

Sel eukariot dapat membelah diri secara aseksual, proses pembelah dirinya secara mitosis. Sel benih organisme eukariotdapat juga melangsungkan konjugasi seksual yang kompleks. Berikut perbandingan antara sel prokariot dan eukariot dapat dilihat pada Tabel 1.

Tabel 1. perbedaan antara sel prokariotdan eukariot

\begin{tabular}{|c|c|c|}
\hline Karakteristik & Sel prokariot & Sel eukariot \\
\hline Bentuk organisasi & Bersel satu & Bersel satu atau banyak \\
\hline $\begin{array}{c}\text { Organel, sitoskelet, } \\
\text { alat pembelahan sel }\end{array}$ & Ada & Rumun rumit \\
\hline DNA & Mudah, didalam sitoplasma & Runti sel \\
\hline $\begin{array}{c}\text { Protein, sintesis dan } \\
\text { pematangan }\end{array}$ & $\begin{array}{c}\text { Sederhana, terangkai dengan } \\
\text { sintesis RNA }\end{array}$ & $\begin{array}{c}\text { Rumit, dalam sitoplasma dan } \\
\text { retikulum endoplasma berbintil }\end{array}$ \\
\hline Metabolisme & $\begin{array}{c}\text { Anaerobik atau aerobik, sangat } \\
\text { mampu menyesuaikan diri }\end{array}$ & Kebanyakan aerobik \\
\hline
\end{tabular}




\begin{tabular}{|c|c|c|}
\hline $\begin{array}{c}\text { Endositisis dan } \\
\text { eksositosis }\end{array}$ & Tidak & Ya \\
\hline
\end{tabular}

\section{Mitokondria}

Mitokondria merupakan organel sel yang diselimuti oleh membran dan ditemukan dalam semua sel eukariot. Berdasarkan hipotesis, endosimbiosis mitokondria berasal dari sel eukariot yang bersimbiosis dengan prokariot (bakteri) sehingga membentuk organel sel. ${ }^{[10]}$ Adanya DNA pada mitokondria menunjukkan bahwa dahulu mitokondria merupakan entitas yang terpisah dari sel inangnya dan hipotesis ini ditunjang oleh beberapa kemiripan mitokondria dengan bakteri.Mitokondria ini menyerupai bakteri mulai dari bereproduksi dengan cara membelah diri menjadi dua; memiliki sistem genetik sendiri; dan memiliki ribosom. Ribosom mitokondria lebih mirip dengan bakteri dibandingkan dengan ribosom yang dikode oleh inti sel eukariot. ${ }^{[11]}$ Strukturmitokondria ditunjukkan pada Gambar3.

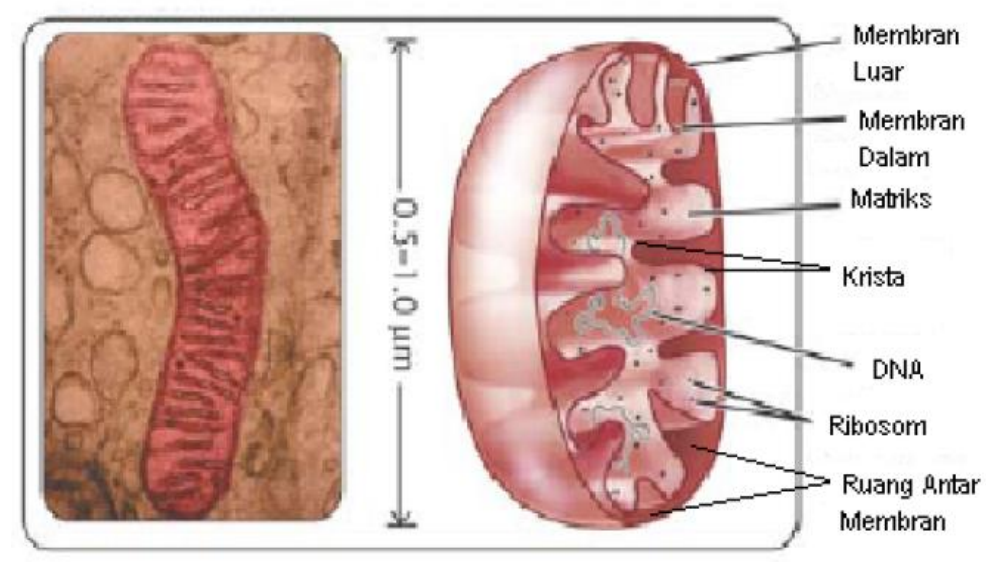

Gambar 3 struktur mitokondria ${ }^{[12]}$

Gambar 3 adalah struktur mitokondria yang merupakan organel sel penting dalam sel eukariot, berbentuk elips, dan memiliki empat bagian penting yaitu: (1) membran luar, (2) ruang antar-membran, (3) membran dalam, dan (4) matriks. Membran luar bersifat permeable; ruang antar membran tempatdihasilkannya nukleotida kinase; membran dalam yang berlekuk-lekuk. Mitokondria pada eukariot berjumlah sangat banyak dan esensial karena tanpa mitokondria maka sel-sel akan mengandalkan proses anaerob untuk menghasilkan ATP.

Mitokondria memiliki berbagai sifat yang unik dibandingkan dengan organel sel lainnya, salah satunya adalah jumlahnya yang berbeda-beda disetiap jaringan. ${ }^{[13]}$ Semakin tinggi kebutuhan jaringan akan energi, maka jumlah mitokondria yang dapat ditemukan juga semakin tinggi. Selain itu, mitokondria juga ditemukan dalam jumlah banyak pada bagian ekor sperma, sel otot jantung, dan sel-sel yang aktif membelah seperti sel epitel, sel folikel akar rambut dan sel epidermis. Hal ini erat kaitannya dengan proses oksidasi zat-zat makanan yang menghasilkan energi dalam bentuk adenosin triposfat (ATP) yang merupakan sumber energi kimia sel. ${ }^{[6]}$

\section{DNA}

\section{Struktur dan Sifat Kimia DNA}

DNA dan RNA merupakan polimer linear (polinukleotida) yang tersusun dari subunit dan monomer nukleotida. Komponen penyusun nukleotida terdiri dari tiga jenis molekul, yaitu gula 
pentosa (deoksiribosa pada DNA atau ribosa pada RNA), basa nitrogen, dan gugus fosfat. Basa nitrogen yang terdapat pada nukleotida adalah basa purin (adenin=A, gunanin= $\mathrm{G}$ ) dan basa pirimidin $($ cytosin $=\mathrm{C}$, timin $=\mathrm{T}$, urasil $=\mathrm{U})$. Timin terutama terdapat pada DNA sedangkan urasil hanya terdapat pada RNA. Monomer nukleotida mempunyai gugus hidroksil pada posisi karbon 3', gugus fosfat pada posisi karbon 5' dan basa pada posisi karbon 1' molekul gula. Nukleotida satu dengan yang lainnya berikatan melalui ikatan fosfodiester antara gugus 5' fosfat dengan 3' hidroksil. $^{[14]}$ Berikut struktur basa nitrogen purin dan pirimidin dapat dilihat padaGambar 4.

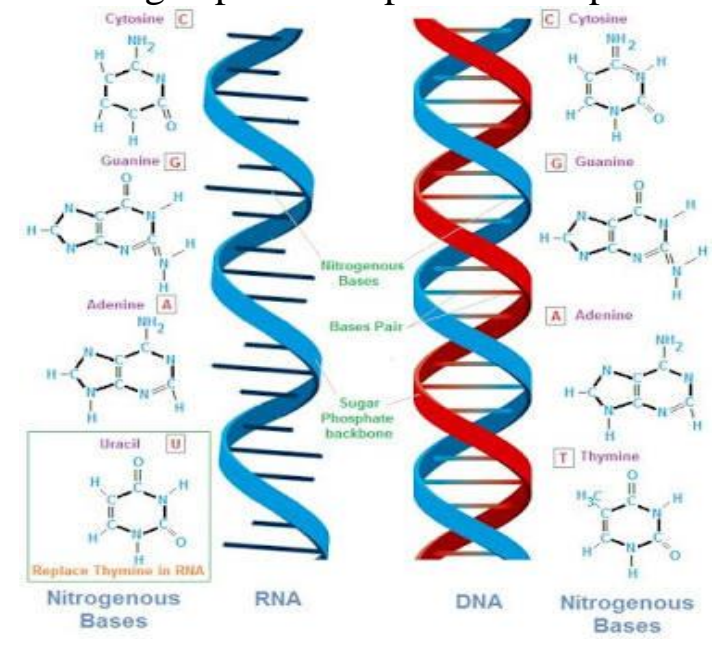

Gambar 4.Sruktur DNA, basa nitrogen purin dan pirimidin. ${ }^{[15]}$

\section{Fungsi DNA}

DNA adalah dasar kimiawi hereditas dan penyusun gen yang menjadi unit fundamental informasi genetik. Informasi genetik yang disimpan dalam nukleotida berfungsi untuk memenuhi dua tujuan, yaitu sumber informasi bagi sintesis semua molekul protein pada sel serta organisme dan memberikan informasi yang diwariskan kepada anak atau generasi berikutnya. ${ }^{[18]}$

\section{DNA Mitokondria}

DNA mitokondria (mtDNA) manusia terletak di dalam matriks mitokondria. mtDNA manusia berupa untai ganda berbentuk sirkuler yang memiliki urutan lengkap nukleotida sepanjang 16.569 pasang basa (pb). Molekul mtDNA terdiri dari untai heavy $(\mathrm{H})$ dan untai light (L). ${ }^{[4]}$ UntaiH ini memiliki basa $G$ lebih banyak dan untai $L$ yang memiliki basa $C$ lebih banyak. ${ }^{[2]}$ DNA mitokondria manusia (Gambar5) tidak memiliki intron dan semua gen pengode terletak berdampingan. ${ }^{[4]}$ Urutan lengkapnya pertama kali ditentukan pada tahun 1981 oleh Aderson et al. dan dikenal dengan sebutan Cambriage Reference Sequence (CRS).

DNA mitokondria pada CSR mengandung 16.569 pasang basa dengan 37 gen pengode (coding redion) yaitu 13 protein, 22 tRNA, 2rRNA dan daerah yang tidak mengode (non coding region) atau daerah pengontrol yang mengandung D-loop. D-loop ini terdiri atas dua daerah dengan variasi tinggi, yaitu hypervariablesegmentI (HVSI) dan hypervariable segment II (HVSII). ${ }^{[4]}$ Gambar struktur DNA mitokondria dapat dilihat pada Gambar5. 


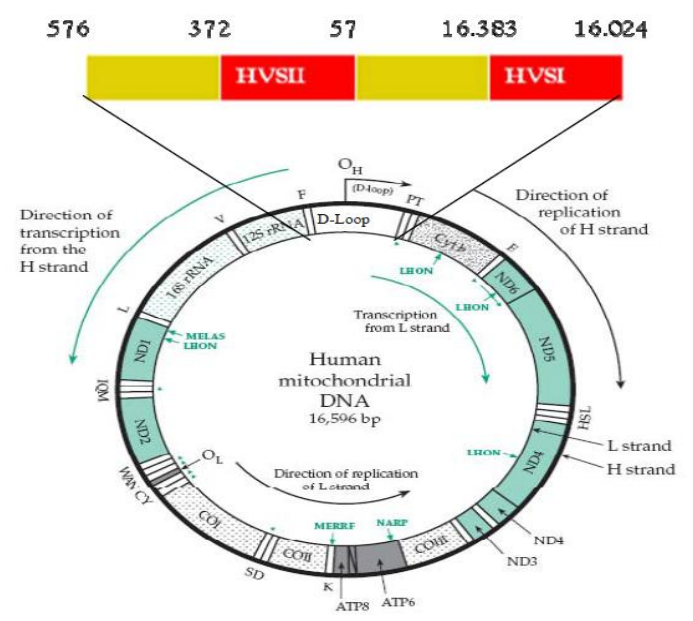

Gambar 5.Struktur DNA mitokondria ${ }^{[21]}$

Secara umum, mtDNA terdiri atas daerah pengode dan daerah non-pengode. Daerah nonpengode memiliki ukuran sepanjang 1122 pb. Daerah non-pengode ini mengandung bagian yang memiliki variasi tinggi pada tiap individu yang disebut dengan displacement loop (D-loop) sehingga seringkali digunakan untuk keperluan filogenetik. D-loop merupakan daerah beruntai tiga (triple stranded), dan untai ketiga ini lebih dikenal dengan nama 7S DNA. Terlihat pada Gambar 5 bahwa D-loop ini memiliki dua daerah yaitu HVSI pada posisi 16024-16265 dan HVSII pada posisi 57-732. Selain D-loop juga terdapat daerah pengontrol non-coding region yang mengandung origin of replication (ORI) untuk untai $\left(\mathrm{O}_{\mathrm{H}}\right)$ dan promotor untuk untai $\mathrm{H}$ dan $\mathrm{L}\left(\mathrm{P}_{\mathrm{L}}\right.$ dan $\left.\mathrm{P}_{\mathrm{H}}\right)$. Selain mengandung daerah dengan variasi tinggi, daerah non coding juga memiliki tiga daerah yang lestari, yang disebut dengan Conserved Sequence Block (CSB) I, II, III. Daerah yang lestari ini diduga memegang peranan penting dalam replikasi DNA.

Berbeda halnya dengan DNA inti, DNA mitokondria diwariskan melalui garis keturunan ibu. ${ }^{[22]}$ Hal ini terjadi karena hampir tidak adanya rekombinasi DNA mitokondria dari ayah dan DNA mitokondria dari ibu saat pembuahan sel telur oleh sperma. Saat terjadi pembuahan, bagian ekor sperma dilepaskan sehingga hampir tidak ada DNA mitokondria dari ayah yang masuk ke dalam sel telur. Selain itu, jumlah kopi mtDNA sel sperma sangat rendah (100-500) sedangkan sel telur memiliki jumlah kopi mtDNA yang tinggi $(\geq 100000) .{ }^{[23]}$ Oleh karena itu, mtDNA bersifat haploid yaitu karena diturunkan dari ibu ke seluruh keturunannya.

\subsection{Polymerase Chain Reaction (PCR)}

PCR merupakan teknik in vitro untuk DNA yang dibatasi oleh sepasang primer (oligonukleotida pendek) menggunakan enzim 17 DNA polimerase dan dNTP sebagai monomermya. ${ }^{[25]}$ Pada umumnya proses PCR berlangsung dalam tiga tahap yaitu: (1). Denaturasi, yaitu pemisahan DNA untai ganda menjadi untai tunggal karena terjadi pemutusan ikatan hidrogen basa-basanya pada suhu tinggi $\left(94-96{ }^{\circ} \mathrm{C}\right)$. (2). Annealing, yaitu tahap penempelan primer pada template DNA. Suhu annealing dapat dihitung berdasarkan nilai melting temperature ${ }^{\mathrm{TM}}$ dari primer-primer yang digunakan. (3). Extension, yaitu tahap reaksipolimerisasi oleh enzim DNA polimerase menggunakan dNTP sebagai monomernya dan dimulai dari ujung 3' primer sepanjang DNA tampletnya hingga berbentuk untai DNA baru. Tahap ini berlangsung pada temperatur saat DNA polimerase bekerja optimal. Waktu yang dibutuhkan pada tahap ekstensi tergantung pada 
panjang fragmen yang diamplifikasi dan kecepatan reaksi (processity) dari enzim DNA polimerase yang digunakan.Ketiga tahap tersebut merupakan siklus yang berlangsung secara terus menerus.Untuk menghasilkan produk yang banyak dibutuhkan sekitar 25-30 siklus. Secara teori jumlah fragmen DNA yang dihasilkan selama $n$ siklus PCR dirumuskan dengan $\left(2^{n}-2 n\right) x$, dimana $\mathrm{n}=$ jumlah siklus, dan $\mathrm{x}=$ jumlah templat DNA $\cdot{ }^{[24]}$ Bahan-bahan yang dibutuhkan agar reaksi amplifikasi dapat berjalan adalah: DNA templat, diperoleh dari sampel yang mengandung fragmen DNA yang diinginkan untuk diperbanyak atau diamplifikasi, Taq buffer (buffer PCR), sebagai penyedia dan penjaga suasana kimia dalam larutan agar enzim polimerase dapat berfungsi dengan baik, Primer, yang digunakan terdiri dari primer forward (maju) dan reverse (balik) yang urutannya merupakan komplemen dari masing-masing untai DNA, dan dNTP, sebagai sumber nukleotida untuk memperpanjang rantai DNA primer yang menjadi daerah awal berjalannya proses perbanyakan.

\section{Elektroforesis Gel Agarosa}

Elektroforesis adalahteknik pemisahan komponen atau molekul bermuatan berdasarkan perbedaan tingkat migrasinya dalam sebuah medan listrik. Kecepatan molekul yang bergerak pada medan listrik bergantung pada muatan, bentuk dan ukuran molekul. Elektroforesis gel biasanya digunakan untuk tujuan analisis, namun dapat pula digunakan untuk separasi makromolekul dan juga sebagai teknik preparatif untuk memurnikan molekul sebelum digunakan dalam metode lain seperti sekuensing, posisi molekul yang terseparasi pada gel dapat dideteksi dengan pewarnaan atau autoradiografi, ataupun dilakukan kuantifikasi dengan densitometer. ${ }^{\text {[27] }}$

\section{METODE PENELITIAN}

Metode yang akan dilakukan dalam penelitian ini terdiri dari pengumpulan sampel; lisis dari sampel mtDNA yang diperoleh; amplifikasi daerah D-loop mtDNA sampel dengan menggunakan teknik PCR (Polymerase Chain Reaction); pendeteksian hasil PCR dengan elektroforesis gel agarosa; sekuensing hasil PCR dengan metode dideoksi sanger; serta analisis urutan nukleotida menggunakan program SeqMan ${ }^{T M}$ versi 4.00 DNASTAR.

\section{HASIL DAN PEMBAHASAN}

\section{Karakteristik sampel epitel rongga mulut}

Tahapan awal dalam penelitian ini adalah pengambilan sampel dari satu garis keturunan ibu di daerah Sukabumi. Karakteristik dari masing-masing sampel secara rinci ditunjukkan pada Tabel 2.

Tabel 2.Data Sampel mtDNA Manusia

\begin{tabular}{|c|c|}
\hline Kode Sampel & Jenis Kelamin \\
\hline K & Perempuan \\
\hline KK & Perempuan \\
\hline
\end{tabular}

Sampel yang diperoleh dengan cara berkumur merupakan campuran yang sangat kompleks, karena selain sel epitel dan senyawa-senyawa yang telah disebutkan di atas, di dalamnya terdapat pula debris sel. Karena ukurannya yang relatif jauh lebih besar dari sel, debris 
dengan mudah dapat dipisahkan dari campuran. Sementara zat-zat organik, anorganik, dan makromolekul terlarut hasil sekresi kelenjar saliva tidak dapat dipisahkan dari campuran. Keberadaan zat-zat tersebut dalam sampel tidak mengganggu reaksi PCR, terbukti dengan berhasilnya amplifikasi yang dilakukan pada penelitian ini.

Banyaknya sel epitel yang dapat terambil dengan cara berkumur tergantung pada jumlah air kumur dan waktu kumur. Makin lama waktu kumur akan makin banyak sel yang terambil. Waktu kumur 1 menit merupakan waktu yang ideal untuk berkumur menggunakan $15 \mu \mathrm{L}$ aquades steril. Makin banyak jumlah air yang digunakan untuk berkumur akan makin encer suspensi yang dihasilkan. ${ }^{[30]}$

\section{Karakteristik sampel folikel akar rambut}

Sampel yang diambil dari satu garis keturunan ibu ini juga diambil dari akar rambut. Hal ini dikarenakan akar rambut dikelilingi folikel. Folikel merupakan pusat tumbuh rambut yang mengandung keratin yang berasal dari invaginasi epitel epidermis, sehingga terdapat lebih banyak mtDNA dibandingkan dengan bagian pangkalnya. ${ }^{[31]}$ Beberapa alasan yang menyebabkan rambut digunakan sebagai sumber mtDNA pada penelitian ini adalah: rambut mengalami pertumbuhan yang relatif cepat, proses pengambilan sampel rambut lebih mudah dibandingkan sel-sel sumber mtDNA lainnya seperti darah, dan penyimpanannya lebih mudah.

\section{Hasil Lisis Sampel}

Pada proses lisis sampel diperoleh fragmen mtDNA yang digunakan sebagai template. Prinsip metode lisis adalah perusakan membran sel tanpa harus merusak DNAyang diinginkan. ${ }^{[32]}$ Templat ini merupakan hasil lisis dari sel epitel rongga mulut dan hasil lisis dari akar rambut yang ditambahkan buffer lisis, proteinase $\mathrm{K}$ dan $\mathrm{ddH}_{2} \mathrm{O}$. Buffer lisis yang digunakan merupakan campuran dari Tris- $\mathrm{HCl} 500 \mu \mathrm{L} \mathrm{pH} \mathrm{8;} \mathrm{EDTA} 20 \mu \mathrm{L} \mathrm{pH} \mathrm{8;} \mathrm{dan} \mathrm{Tween-20} \mathrm{5 \% .} \mathrm{Tris-}$ $\mathrm{HCl}$ berfungsi untuk menjaga $\mathrm{pH}$ optimum pada aktivasi enzim proteinase K. Pada buffer lisis, larutan EDTA (Ethylendiamine tetraacetic acid)berfungsi sebagai pembentuk kompleks kelat dengan ion logam, seperti $\mathrm{Mg}^{2+}$ yang merupakan kofaktor DNA polimerase III. Pembentuk kompleks ini menyebabkan DNA polymerase III menjadi tidak aktif sehingga DNA polymerase III tidak memecah molekul DNA. ${ }^{[31]}$ Tween-20 berperan sebagai detergen atau pengemulsi. Proteinase-K yang ditambahkan dalam larutan lisis berfungsi untuk menghancurkan atau mendegrasdasi protein penyusun komponen sel.

Dalam tahap lisis dilakukan inkubasi pada suhu $50{ }^{\circ} \mathrm{C}$ selama 60 menit. Inkubasi ini berperan untuk mengoptimalkan kerja enzim proteinase- $\mathrm{K}$ dalam mendegradasi protein serta mengoptimalkan reaksi lisis membran sel oleh Tris-HCl, EDTA, dan Twen 20. Proteinase K dalam mtDNA dideaktifasi dengan pemanasan pada suhu $95^{\circ} \mathrm{C}$ agar tidak merusak molekulmolekul proteinnya. Dengan demikian diperoleh templat mtDNA hasil lisis yang terlarut pada supernatannya dan sudah terpisah dari debrisnya. Templat mtDNA yang diperoleh disimpan pada suhu $-20{ }^{\circ} \mathrm{C}$ untuk menjaga kondisi fisiologis mtDNA.

Primer-primer dirancang menggunakan program seqman DNA star. Rancangan primer dibuat dengan memasukan urutan D-loop mtDNA yang diperoleh dari NCBI. Database yang diperoleh dari NCBI dimasukkan kedalam program seqman DNA star kemudian primer yang digunakan dimasukkan kedalam program seqman DNA star. Perancang primer yang baik harus mempertimbangkan beberapa peraturan, yakni memeperlihatkan besarnya amplikon, panjang 
primer, titik leleh, dan tidak membentuk struktur sekunder. Berikut Gambar 6rancangan primer majuM1 menggunakan program seqman DNA star. ${ }^{[29]}$

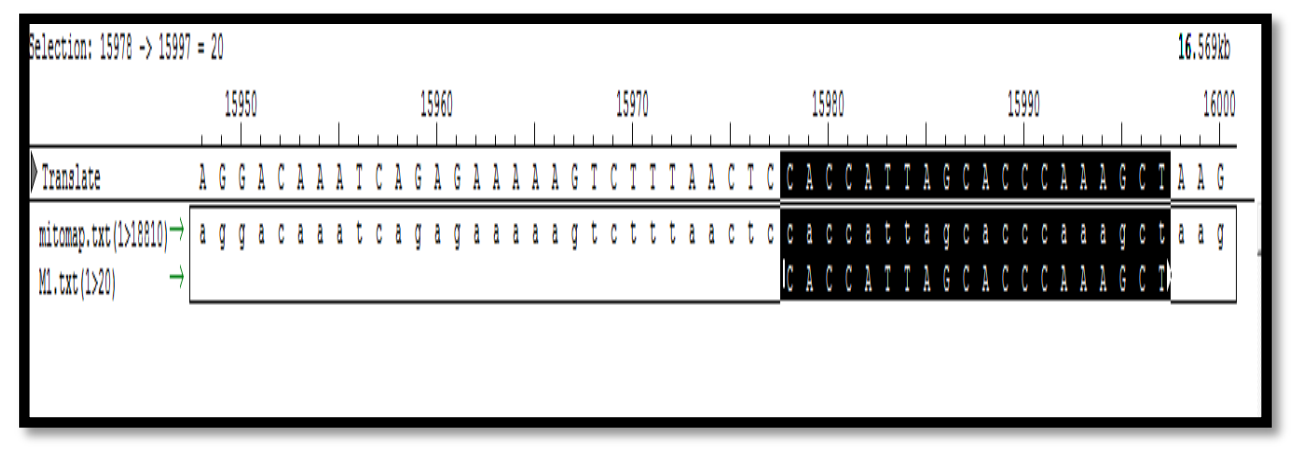

Gambar 6 Primer majuM1menggunakan program seqman DNA star

Primer yang didapatkan dengan menggunakan program seqman DNA star merupakan primer universal untuk mengidentifikan daerah D-loop mtDNA. Primer maju dimulai dari 15.978-15997 pb. Panjang primer maju20pb hal ini sesuai dengan persyaratan panjang primer yang baik adalah $18-22 \mathrm{pb}$. Suhu annealing untuk primer ini adalah $50^{\circ} \mathrm{C}$ hal ini sesuai dengan persyaratan primer yang baik yaitu sekitar $50-58^{\circ} \mathrm{C}$. Berikut Gambar 7rancangan primer balikM2 menggunakan program seqman DNA star. ${ }^{[29]}$

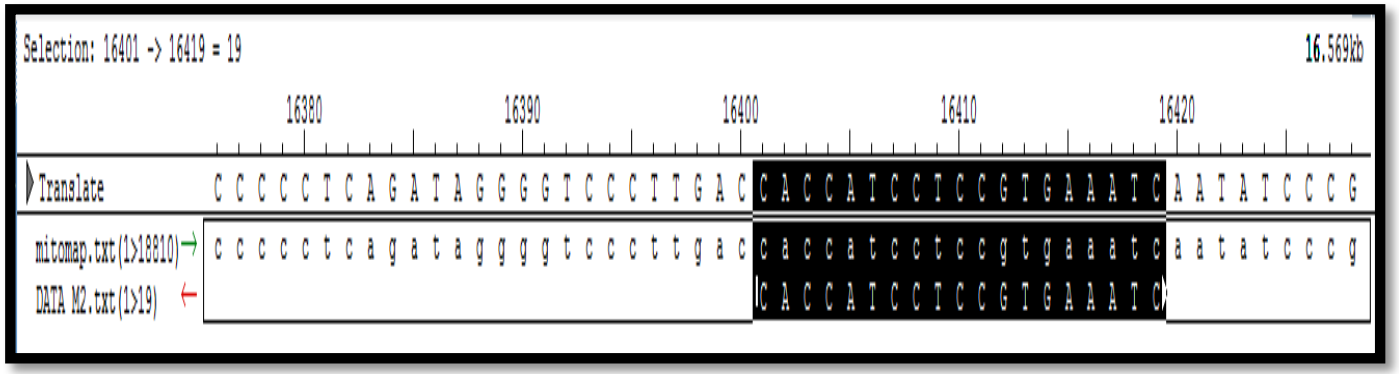

Gambar 7 PrimerbalikM2 menggunakan program seqman DNA star.

Primerbalik dimulai pada panjang basa 16.401-16.419pb. panjang primer balik 19pb, hal ini sesuai dengan persyaratan panjang primer yang baik yaitu 18-22pb. Suhu annealing untuk primer ini adalah $50^{\circ} \mathrm{C}$ hal ini sesuai dengan persyaratan primer yang baik $50-58^{\circ} \mathrm{C}$. Berikut Gambar 8rancangan primer balikHV2R menggunakan program seqman DNA star. ${ }^{[29]}$ Primerbalik dimulai pada panjang basa $409-429 \mathrm{pb}$. panjang primer balik $21 \mathrm{pb}$, hal ini sesuai dengan persyaratan panjang primer yang baik yaitu 18-22pb. Suhu annealing untukprimer ini adalah $50^{\circ} \mathrm{C}$ hal ini sesuai dengan persyaratan primer yang baik $50-58^{\circ} \mathrm{C}$. ${ }^{[2]}$

\section{Analisis Hasil PCR}

Hasil PCR kemudian dianalisis menggunakan metode elektroforesis gel agarosa dan visualisasi dapat dilihat di bawah sinar $U V$. Metode ini mampu memperlihatkan ukuran fragmen hasil PCR yang diperoleh dalam penelitian. Untuk menentukan ukuran hasil PCR digunakan penanda (marker) DNA ladder KAPA Universal, dan $1 \mathrm{~kb}$ ladder (fermentas) dengan ukuran 
pasang basa tertentu. Keberhasilan amplifikasi diidentifikasi dengan cara membandingkan posisi fragmen sampel dengan marker DNA yang sudah diketahui ukurannya dan meyakinkan bahwa mtDNA yang diamplifikasi merupakan mtDNA targen bukan asing.

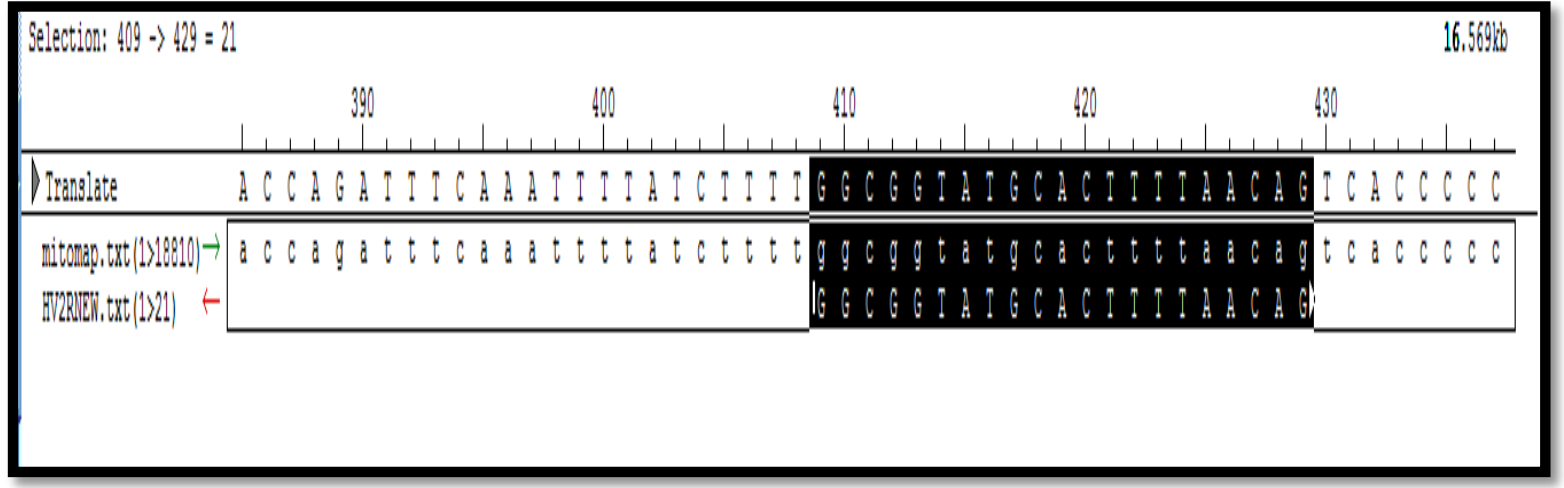

Gambar 8.Primer balikHV2R menggunakan program seqman DNA star

Pada proses elektroforesis gel agarosa digunakan DNA ladder KAPA Universal dan $1 \mathrm{~kb}$ ladder fermentas sebagai marker. DNA ladder KAPA Universal menghasilkan delapan belas fragmen dan $1 \mathrm{~kb}$ ladder fermentas menghasilkan empat belas fragmen. Hasil deteksi produk PCR dengan teknik elektroforesis gel agarosa $1 \%$ pada sampel sel epitel rongga mulut menggunakan primer M1 dan HV2R dapat dilihat pada Gambar 9, Gambar 10, dan pada sampel sel folikel akar rambut menggunakan primer M1 dan M2 dapat dilihat pada Gambar 12.

Hasil produk PCR sampel sel epitel rongga mulut pada Gambar 9menunjukkan adanya pita fragmen yang sejajar dengan sampel positif K terletak pada ukuran 1000 pb, primer yang digunakan adalah primer M1 dan HV2R. Hasil PCR tersebut merupakan fragmen D-loop mtDNA manusia yang dimulai dari nukleotida 15.978 hingga nukleotida $16.420 .{ }^{[1]}$ dan pita marker yang dihasilkan cukup sempurna karena pada saat penyimpanan marker suhu ruang cukup lama sekitar 3-4 jam.

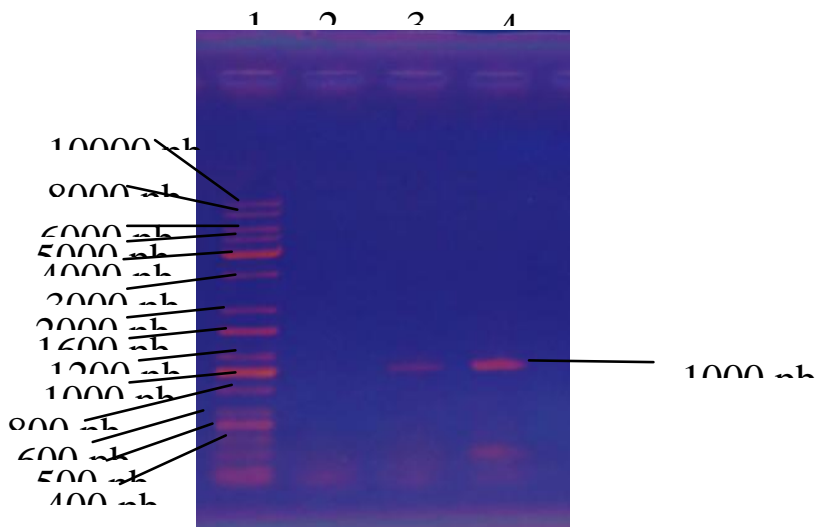

Gambar 9.Hasil deteksi produk PCR sampel sel epitel rongga mulut dengan elektroforesis gel agarosa. Lajur 1 menunjukkan marker DNA ladder KAPA Universal; lajur 2 menunjukkankontrol negatif; lajur 3 sampel positif K dan 4 sampel KK 
Amplifikasi PCR berhasil diamati dengan bantuan gel agarosa sebagai pita tunggal DNA yang diperkirakan berukuran $1000 \mathrm{pb}$ (Gambar 10). proses PCR dikontrol oleh kontrol positif yang mengandung templat DNA yang telah pernah berhasil diamplifikasi. Seperti terlihat pada lajur 2, kontrol positif menghasilkan satu pita fragmen berukuran 1000 pb. Hasil ini menunjukkan bahwa proses PCR yang dilakukan berhasil.

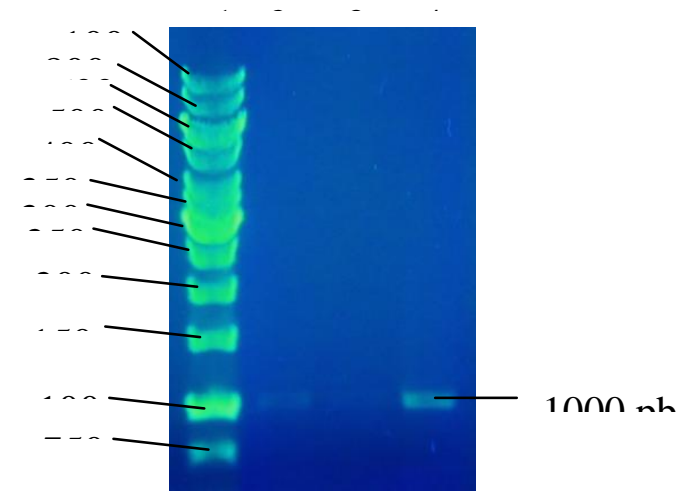

Gambar10. lajur 1 menunjukkan marker $1 \mathrm{~kb}$ ladder fermantas; lajur 2 menunjukkan kontrol positif ; lajur 3 sampel positif K dan 4 sampel KK.

Ukuran fragmen PCR dapat dihitung berdasarkan selisih total pasang basa dalam mtDNA (16569) dengan posisi awal primer M1 (L15978) dan posisi akhir HV2R (H409) + 1. Berdasarkan perhitungan tersebut diperoleh ukuran fragmen hasil PCR adalah 1002 pasang basa. Posisi ukuran fragmen tersebut berada di daerah D-Loop yang digambarkan dalam bentuk diagram dapat dilihat pada Gambar 11.Gambar tersebutmenunjukan pada posisi ukuran fragmen hasil PCR pada daerah D-loop, fragmen 592 menunjukkan selisih total pasangan basa dalam mtDNA (16569pb) dengan posisi awal primer M1 (L15978), fragmen 409 pb merupakan posisi akhir HV2R (H409). Fragmen 1002 pb menunjukkan ukuran fragmen hasil PCR. Primer M1 ditunjukan dengan warna biru, primer HV2R ditunjukkan dengan warna merah. Daerah HV1 ditunjukkan dengan warna hijau, daerah HV2 ditunjukkan dengan warna ungu. Warna orange menunjukkan daerah antara HV1 dan HV2.

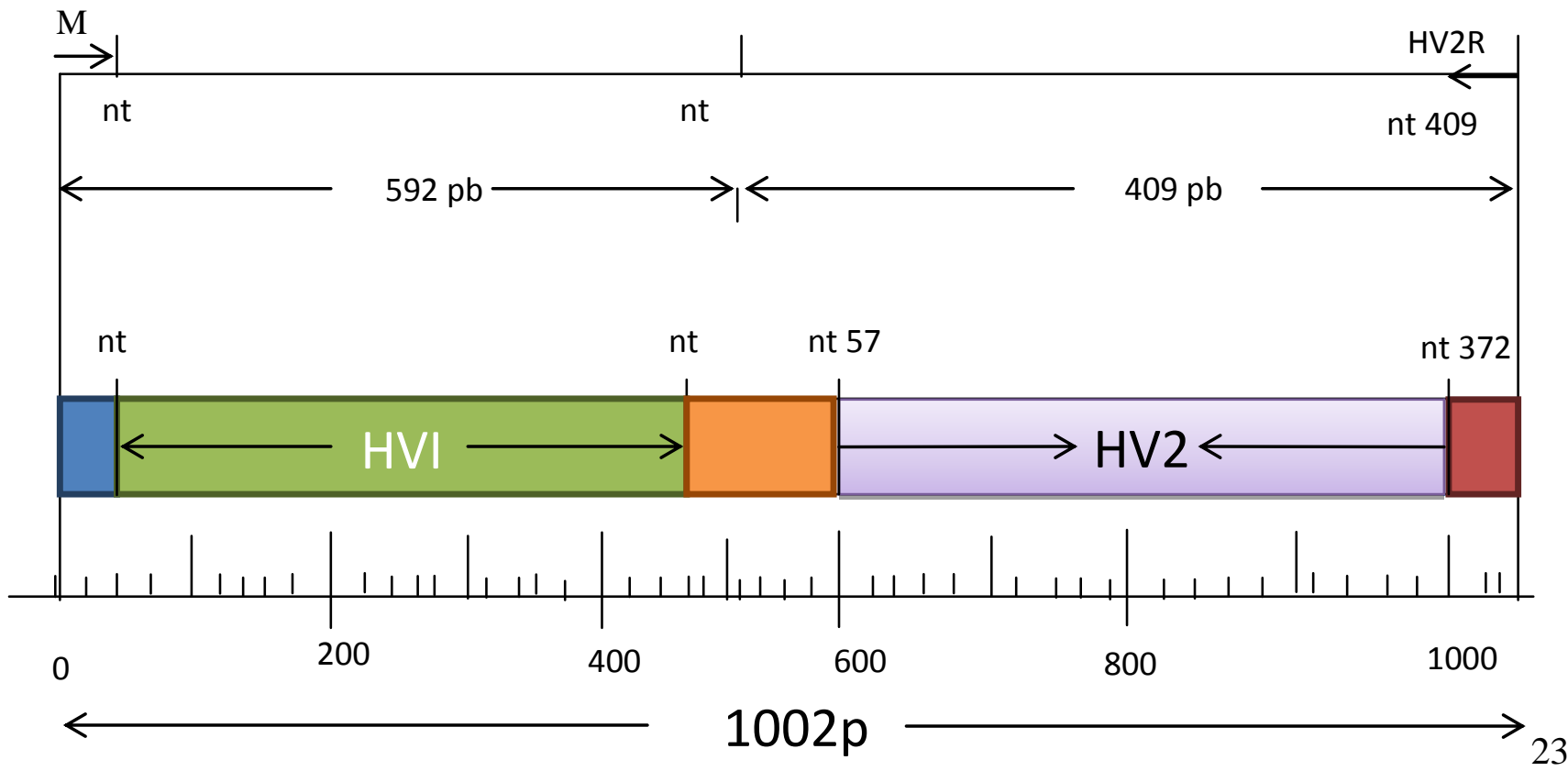


Gambar 11. posisi ukuran fragmen hasil PCR pada daerah D-Loop

Hasil PCR dari dua sampel $(\mathrm{k}, \mathrm{kk})$ dipeoleh fragmen mtDNA berukuran sekitar $400 \mathrm{pb}$ $(0,4 \mathrm{~kb})$, ditunjukkan oleh pita yang berada pada laju 3 dan 6 pada marker DNA ladder KAPA universal, seperti terlihat pada Gambar 12. Hasil ini sesuai prediksi, yaitu fragmen $442 \mathrm{pb}$ daerah D-loop mtDNA pada posisi 15.978-16419. ${ }^{[11]}$

Ukuran fragmen PCR dapat dihitung berdasarkan selisih total pasang basa dalam mtDNA (16569) dengan posisi awal primer M1 (L15978) dan posisi akhir M2 (H16419). Berdasarkan perhitungan tersebut diperoleh ukuran fragmen hasil PCR adalah 442 pasang basa. Posisi ukuran fragmen tersebut berada di daerah D-Loop yang digambarkan dalam bentuk diagram dapat dilihat pada Gambar 12.

$$
136
$$

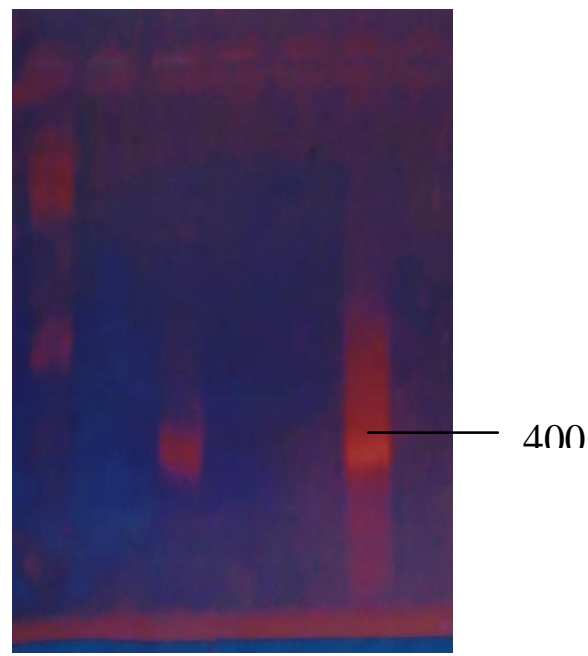

Gambar 12.Hasil deteksi produk PCR dengan elektroforesis gel agarosa sampel produk PCR folikel akar rambut dengan primer M1 M2. Lajur 1 menunjukkan marker DNA ladder KAPA Universal; lajur 2 menunjukkan kontrol negatif; lajur 3 menunjukkan sampel positif K; lajur 6 menunjukkan sampel KK.

Pada Gambar 12posisi ukuran fragmen hasil PCR pada daerah D-loop, fragmen 442 menunjukkan selisih total pasanan basa dalam mtDNA (16569pb) dengan posisi awal primer M1 (L15978), fragmen $16219 \mathrm{pb}$ merupakan posisi akhir M2 (H16419). Fragmen $442 \mathrm{pb}$ menunjukkan ukuran fragmen hasil PCR. Primer M1 ditunjukan dengan warna biru, primer M2 ditunjukkan dengan warna oranye. 


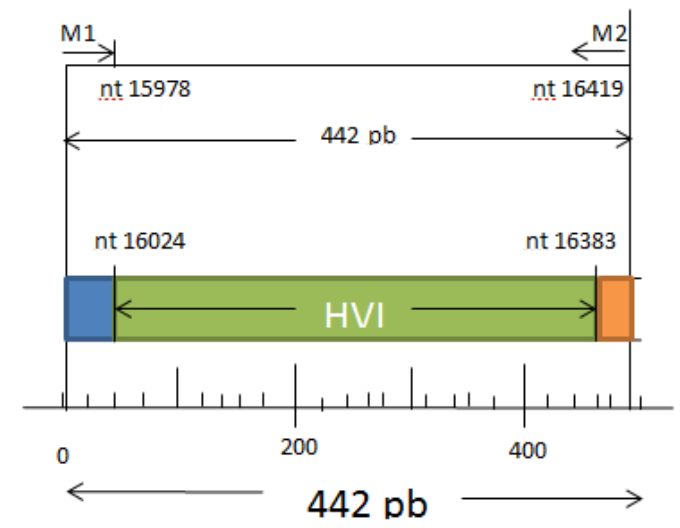

Gambar 13. posisi ukuran fragmen hasil PCR pada daerah D-Loop

\section{Hasil Sekuensing}

Setelah berhasil dilakukan amplifikasi atau perbanyakan sampel satu garis keturunan ibu dan divisualisasika melalui elektroforesis gel agarosa yang mengindikasi bahwa sampel hasil PCR berhasil mengamplifikasi fragmen DNA pada sel epitel rongga mulut berukuran $1 \mathrm{~kb}$ dan pada sel folikel akar rambut berukuran $0,4 \mathrm{~kb}$, maka hasil sampel PCR tersebut kemudian diproses dengan sekuensing. Proses sekuensing ini bertujuan untuk menganalisis urutan nukleotida sampel satu garis keturunan ibu. Berikut gambar hasilsekuensingsampel satu garis keturunan ibu dapat dilihat pada Gambar 14.

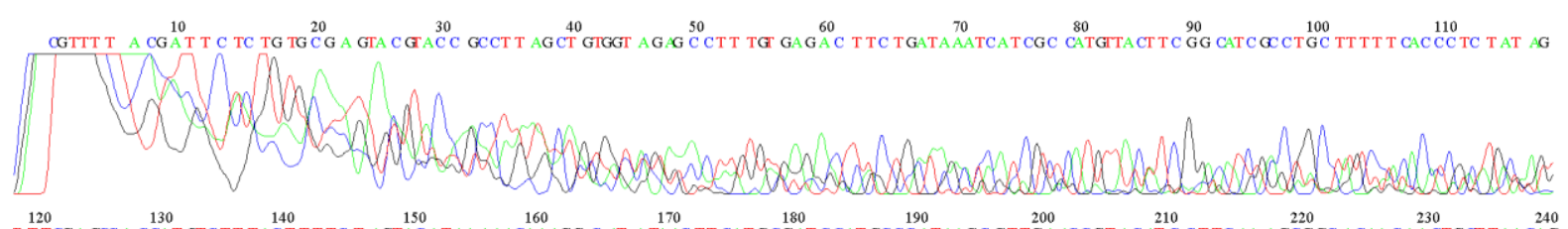

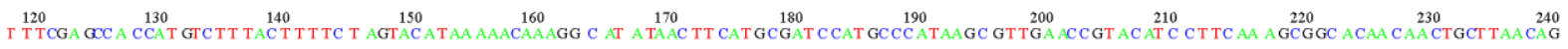

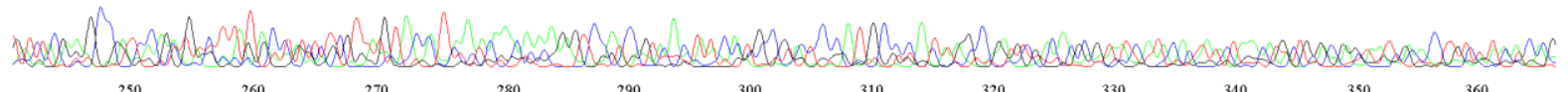

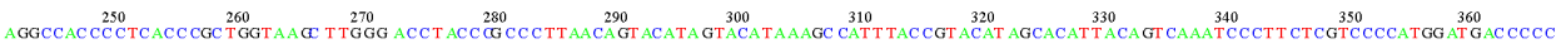
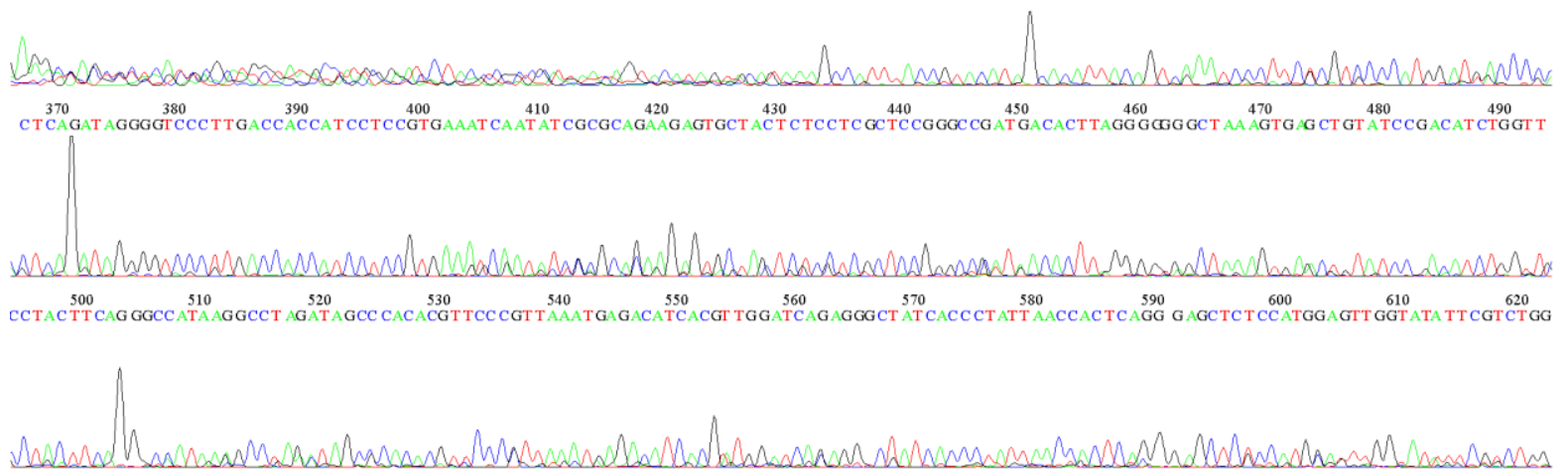

Gambar 14. Tampilan sekuensing sampel satu garis keturunan ibu 


\section{KESIMPULAN}

Berdasarkan penelitian tersebut dapat disimpulkan bahwa amplifikasi fragmen DNA mitokondria menggunakan primer M1 dan HV2R dari sel epirel rongga mulut menghasilkan fragmen berukuran $1 \mathrm{~kb}$. Pada hasil amplifikasi fragmen DNA mitokondria dari sel folikel akar rambut menggunakan primer M1 dan M2, fragmen yang didapatkan berukuran 0,4-0,5 kb. Dengan demikian, fragmen DNA mitokondria dapat diamplifikasi menggunakan dua primer balik M2 dan HV2R yang dirancang pada ujung daerah D-LOOP mitokondria.

Akan tetapi hasil sekuensing yang dilakukan tidak dianalisis urutan nukleotida nya karena hasil sekuensing yang didapat tidak sempurna sehingga tidak bisa menentukan terjadi mutasi atau tidak terjadinya mutasi.

\section{DAFTAR PUSTAKA}

Cambell, dkk., 2002. Biologi (Edisi Kelima). Jakarta: Erlangga.

Wallace, D.C., 1997: Miochondrial DNA in Again Disease. Scientific American. 22-29

Moore, J.M., Insenberg, A.R., 1999, Mitochondrial DNA Analysis at the FBI Laboratory, Forensic Science Communicatioj, vol. I, Number 2.

Marks, D.B., Marks, A.D, Smith,C.M. 1996. Basic Medical Biochemistry. Williams \& Wilkins. Baltimore.

Poedjiadi, Anna dan Supriyanti F.M.T. 2006. Dasar-dasar Biokimia. Jakarta: Universitas Indonesia Press).

Marguillis, L., 1981. Symbiosis In Cell Evolution.New New ork:W.H. Freman .

Lehninger, Albert L. 1982. Dasar-dasar Biokimia. Jakarta: Erlangga.

Andrey.2004.Biopsikologi.[Online].Tersedia:https://Andreyagheanayaa.blogspot.co.id/2004/10/b iopsokologi.html.[05 Maret 2016]

Perpustakaan.2012.StrukturSelEukariot.[Online]Tersedia:https://Perpustakaancyber.blogspot.co. id/2012/11/struktur-sel-eukariot-fungsi.html. [05 Maret 2016]

Lynn, Stephen, et al. 2002. Defining the Importance of mitochondrial Gene Defects in Maternally Inherited diabetes by sequencing the Entire Mitochondrial Genome. Diabetes 5, 2317-2320.

Anderson, S., et al, 1981, Sequence and Organization of the human mitochondrial genome, Nature, 290,457-465.

Fabio,fuady.2008.[Online] GenomMitokondria.Tersedia:https://fuadyfabiounsode.wordpres.com/ 2008/09/genom-mitokondria-manusia.html. [22 Desember 2015]

Brown, W.M., E.M. Prager, A Wang, and A.c. Wilson. 1982. Mitochondrial DNA Sequences of Primates: Tempo and Mode of Evolution.J. mol. Vol (18:225-239).

Gaffar, Shabrani, M.Si. 2007. Buku Ajar Bioteknologi Molekul. Bandung: FMIPA Universitas Padjajaran.

Biotechimylife.2011.[Online]Tersedia:https://biotechismylife.blogspot.co.id/2011/09/struktur.D NA.html. [05 Maret 2016].

Muladno, 2010. Teknologi Rekayasa Genetik Edisi Keda. Bogor : IPB Press.

Watson, James D., John tooze, \& David T. Kurtz, 1988. DNA Rekombinan, alih bahasa: Wisnu Gunarno. Jakarta : Penerbit Erlangga.

Granner, D.K. Biokimia Harper edisi ke-24 :alih bahasa, Andry Hartono; editor. Alexander H. Santoso. Jakarta: EGC Penerbit Buku Kedokteran. 
Saiyed. Z.M., C.N. Ramchand. 2007 Extrzction of Genomic DNA Using Magnetic Nanoparticle $\left(\mathrm{Fe}_{3} \mathrm{O}_{4}\right)$ as Solid-Phase Support. American Journal of Infectious Disease 3 (4): 225-229, 2007.

Promega. 2007. Technical Manual Maxwell 16 DNA Purification Kits. Tersedia: http://www.roche-applied-science.com.

Chen et al, 2004. Maternally Inherited Diabetes and Deafness (MIDD) Syndrome: a Clinical and Molecular Genetikc Study of a Taiwanse Family. Chang Gung Med Journal 27,(1), 66-72.

Wallace, D.C., 1992: Diseases of the mitochondrial DNA, Annu Rev Biochem, 61, 1175-1212.

Faatih, M. 2009: Isolasi dan Digesti DNA Kromosomal. Jurnal Penelitian Sains dan Teknologi, 10(1): 61-67.

Sundaland.2012.[Online].Tersedia:https://Sundaland.gunungtoba.blogspot.co.id/2015/05/mengu pas pewarisan tes DNA.html. [22 Desember 2015].

Sutikno. 2009. Elektroforesis.http://sutikno.blog.uns.ac.id/2009/06/19/elektroforesis/. [13 Januari 2014].

Gumilar, G., Supriyanti, F. M. T., Siti, H. H. 2008. Bioteknologi. Bandung: Jurusan Pendidikan Kimia FPMIPA UPI.

A. Saifuddin Noer dan Marisa Gustiananda., 1997. PCR Tanpa Isolasi DNA dari Sel Epitel Rongga Mulut. Bandung: Jurusan Kimia FMIPA ITB. Vol 2 No. 1, hal, 35-48.

Purnomo, Sudjiono, T. Joko, dan S. Hadisusanto. 2009. Biologi Kelas XI untuk SMA dan MA. Jakarta : Pusat Perbukuan, Departemen Pendidikan Nasional.

Purnamasari, Yunita., 2013. Varian Genetika Daerah Hipervariabel I (HVI) DNA Mitokondria pada 4 Generasi DEngan Riwayat Diabetes Melitus Tipe 2. Bandung: Universitas Pendidikan Indonesia.

Qiagen. 2006. Genomic DNA Purification. [Online]. Tersedia. http://www.qiagen.com/literature /brochurs/index. [24 September 2015].

Aris. T. W,. 2000. Inverse Polumerase Chain Reaction. Jurnal Hayati. Vol 7 (4): 121-123.

Innis. M.A., Gelfand D H, Srinsky. J.J, White. T. J. 1990. PCR Protocols A Guide to Methods and Applications. Academic Press Inc.

Madej, R. 1991. Polymerase Chain Reaction :Application to The Clinical Laboratory. Laboratory Roche Diagnostic Research, p. 23-32, 45-49.

Sambrook, J. Russel DW. 2001. Molecular Cloning: A Laboratoty Manual 3rd edition. New York (USA): Cold Spring Harbor. 